\title{
Inquiry hears claim of threats over lab move
}

Jim Giles, London

Some of Britain's most eminent academics are embroiled in an unseemly public squabble over plans to relocate a prestigious London research institute.

At a House of Commons select committee inquiry on 1 December, neuroscientist Colin Blakemore, head of the Medical Research Council (MRC), was accused of inappropriately influencing the task force investigating site options for the National Institute for Medical Research (NIMR). One task-force member said that Blakemore threatened his job if he opposed plans to relocate the institute. Blakemore denies the allegations.

The future of the NIMR has been hotly debated for the past two years. Some, including Blakemore, argue that the facility should move from its current home in Mill Hill, a suburb of London, to a site closer to a London university and hospital, to speed the translation of basic science into clinical advances. But most NIMR staff say they could improve external collaborations without moving.

A ten-member task force was recruited in June 2003 to study the options. This July, they issued a report backing a move to a London university provided the partnership would be better than if the facility remained in Mill Hill. But NIMR staff say that a briefing note on this report was sent to the MRC's ruling council in July stating that the institute's future lay either with King's College London or University College London, ignoring the option of staying put. Blakemore counters that NIMR staff feelings were explained to the council in another document.

The House of Commons Select Committee on Science and Technology launched an inquiry in October into the matter after hearing complaints about this and other events.

One NIMR researcher on the task force, developmental geneticist Robin Lovell-Badge, testified that Blakemore called him and said, "I don't know how you can disagree with me, I am your employer", which Lovell-Badge

interpreted as a threat. Blakemore "absolutely denies" making any such statement.

Blakemore feels that the allegations are part of a campaign to discredit him and hence affect the decision of the council, which has so far backed a move. "I'm shocked that they feel my career is expendable if it means they get to stay at Mill Hill," he says.

Blakemore presented the inquiry with a document, signed by most members of the task force, stating that its work was "properly conducted" and that the panel had been "united". One member, Paul Nurse, who is president of Rockefeller University in New York, says the phrase "without coercion" was removed from an earlier version of this document in an attempt to convince more members to sign it - although Lovell-Badge and another NIMR worker still did not sign. Nurse says the task-force discussions were closer to "healthy persuasion" than "coercion". Other task-force members agree. "Blakemore behaved with integrity throughout," says Steve Tomlinson, deputy vicechancellor of Cardiff University.

The select committee is due to meet again on 8 December to decide whether to continue the inquiry. The MRC will consider sites for the institute on 15 December, although a decision is not expected until next year.

\section{Move afoot to lend bioweapons treaty more muscle}

\section{Declan Butler, Paris}

An international rapid-reaction unit to investigate bioweapons incidents is being discussed this week at a meeting in Geneva of the parties to the Biological Weapons Convention (BWC).

The treaty, which has been in force since 1975, outlaws states from developing, stockpiling or using biological weapons. But efforts to give it a mechanism for checking whether states comply with its terms were blocked by the United States in 2001 (see Nature 414,$675 ; 2001$ ) and are still in limbo.

With no broad verification scheme expected any time soon, supporters of tougher checks are trying to promote less ambitious alternatives. The proposed rapid-reaction unit, for example, which is being championed by Britain, would be limited to fact-finding missions after an alleged bioweapons incident had taken place. It would have no powers to investigate allegations that a state or plant was manufacturing bioweapons.

A rapid-response unit would at least give the BWC some teeth, its advocates say, and planning for it will force the treaty's 152 parties to discuss technical and other issues relevant to wider verification procedures. This would include drafting lists of experts, equipment and transport, as well as agreements on procedures for handling samples and carrying out laboratory tests.

Angela Woodward, a disarmament specialist at the non-profit Verification Research, Training and Information Centre based in London, points out that Kofi Annan, the director-general of the United Nations (UN), already has powers to call for investigations of alleged chemical or bioweapons uses under a 1989 UN law.

The law was developed with chemical weapons in mind, and has become largely redundant since the Chemical Weapons Convention was equipped with its own verification procedures in 1997. But it could be resuscitated relatively simply, Woodward says, and adapted for bioweapons fact-finding missions.

A working paper drafted by UK experts agrees that the law has not "been reviewed or updated" since 1989. "It is therefore now time to re-establish an effective United Nations procedure for investigating allegations of biological weapons use or suspicious outbreaks of disease," the paper says. It argues that the BWC could guide an update of the law to take account of the specific needs of a rapid-response unit.

This week's meeting is one of three annual summits intended to keep discussion on bioweapons alive before the next major negotiations on the BWC in 2006. It will discuss the rapid-response proposal but will not take a decision on whether to implement it. Advocates hope, however, that the meeting will pave the way for putting the proposal on the agenda at the UN general assembly next year. 